\title{
The Impact of Some Modes of Women Liberation to African Christian Families: A Case of Kagio Town in Kirinyaga County
}

\author{
Phyllis Wangui Kirima
}

School of Education, Mount Kenya University

Doi:10.5901/mjss.2014.v5n5p

\begin{abstract}
The contemporary African Christian family is ideally a harmonious monogamous relation or union between two people of the opposite gender- a male and a female- and is largely nuclear. This family setting has continued to increasingly face a lot of challenges, threatening its well-being and existence. Some of these challenges include: increased cases of divorce, suicidemurder of spouses and children, separations, suicide of children, increased rate of single parenthood, among other concerns. These problems are largely relational in nature and attributed to impossible or problematic relationships between the spouses. Owing to the centrality of the family to the well-being of the society, the cry of an ailing and hurting family cannot be ignored. The African Christian family has encountered many waves of changes and challenges, some which have aimed at making it a better institution and others which have left it maimed and in turmoil. The study is on gender relations in the family and how some modes of women liberation have impacted on the nature of gender relations in the African Christian family and therefore the family as a whole. This study is based in Kagio town in Kirinyaga County. An understanding of the ideal African Christian family, which is an inculturative product of the African and the Christian traditions, is provided.
\end{abstract}

Keywords: Women, Gender, Religion, Christian, African

\section{Background}

History has it that men and women are supposed to exist and co-exist in harmonious interpersonal relationships, as brothers and sisters, husbands and wives, fathers and daughters, mothers and sons, or co-workers. ${ }^{1}$ These relationships are evident within a family setting, whether in the African society, western society, eastern society, modern or traditional.

The African traditional family was mainly patriarchal. Patriarchy was emphasized by such as; patria-local residence after marriage, naming of children with emphasis on naming after the fathers and by the authority bestowed upon the man or men in the family lineage. Marriage was highly emphasized, and most communities socialized and prepared young ones for adult married life. Individuals, who did not appreciate marriage or family, were viewed with suspicion. Marriage was celebrated with lots of joy and enthusiasm and soon after marriage, children were waited for anxiously. It was felt that a marriage without children was not a marriage at all. Re-marriage was allowed in case a wife was not able to bear children. Certain traditional societies formalized the marriage only after children were born. Others even practiced levirate marriage or ghost marriage only to ensure the bringing forth of children and thus continuity, in case the husband had died. The practice of polygamy was allowed in both the form of polygyny and polyandry. Most African marriages and family units were to be entered into with the goal of making them lifetime union. Divorce was thus to be avoided as much as possible. Where divorce took place parental interest and support continued. Domestic work for the males was not emphasized, by the traditional socio-cultural values and most communities out rightly objected to such participation by men. Extended family system was a common feature and therefore family members not only valued and associated closely with their immediate kin but also extended blood relations.

There was limited freedom in communication between parents and children but this was solved by exposing children to a large network of aunts, uncles, grandmothers and fathers. The children shared intimate queries without feeling uncomfortable or shy with these kin. The African traditional family has undergone various transformations in structure, form and functioning. The onset of the $18^{\text {th }}$ century saw the entourage of the Christian teaching and traditions into the Kenyan society. There were several key teachings on the family that contradicted as well as affirmed African traditional values and were required to be adopted by anyone who converted to the Christian faith. Some of the teachings included: the emphasis on monogamy, emphasis on communal way of life but not on basis of blood or tribal relations, individual responsibility on ones choices and actions and prohibition of divorce.

${ }^{1}$ P.N.Wachege, African Women Liberation, A Man's Perspective, 1992, pp15 
There also came in technological advancement, urbanization, modernity and the forces and ideologies of secularization. These phenomenons have as well contributed to social and cultural changes which have affected the nature of the family. Marrying and divorcing has almost become a norm, and is no longer viewed with much contempt. Quasi families have become common place with a majority of female headed household, not only as a result of the death of spouses but also out of preference for such. Emphasis on extended ties has been reduced, with engagement of aunties, uncles and grandparents in parenting almost fading away. Preference for education and career advancement, has led to fewer women getting into early marriages or not getting into marriage at all.

Nevertheless, African traditional values and culture have been resilient in the face of all the above forces of change. This has resulted to a continued tug of war between the various worldviews and ideologies. For instance it is not uncommon to find a monogamous Christian married man, keeping a string of 'wives' or 'mistresses', or the expectation of payment of dowry as much as the Christian marriage does not necessitate payment of dowry. ${ }^{2}$

It is against this similar background that the challenges of the family as a result of women liberation have emanated. Gender related differences have been perceived, interpreted and understood in different ways. The need to address these differences has increased over the years and different stakeholders with different paradigms of thoughts and approaches have come on board. Among them is the feminist / women liberation movement. In the effort to address gender related differences, the feminists/ women liberation movement have largely been preoccupied with advocacy and campaigning for equality and women rights and interests in the society. Less of the women at home and much of them in the workplace, may have led to negating or delegating of primary marital and parental responsibilities, contradicting the very expectations in both the Christian and African family norms. The level of assertion and independence acquired by the women through liberation initiatives, has also contradicted the inherent or socially constructed male ego and patriarchal dominance and responsibility in the African- Christian culture. This has resulted to crises in gender relations, the success of which determines family stability.

In reference to the papal encyclical" Mulieris Digintatem" in the explanation of Genesis (2:18-23), the equality and fundamental partnerships between man and woman is clearly pointed out for fulfilled interpersonal relationships between men and women. Both male and female partners are viewed as complementary beings and therefore whatever role is played should be mutually beneficial across genders. A recent study by the Kenya Agricultural Research Institute (kari) in Imenti south district affirmed the above assertions. The study revealed that, successful commercial banana farming is breaking up homes, turning men into drunkards and putting more burdens on women. Women are said to have massively taken up commercial banana farming, renting own lands and managing personal bank accounts, with $32 \%$ of women having accounts compared to $26 \%$ of the men. The disempowered men spend time at local markets playing games called maune or drinking local brews. Children no longer ask for school fees from their fathers, nor do wives look up to their husbands as breadwinners. These wives are shouldering heavier family burden even after being empowered through banana farming, since despite taking up the role of breadwinning they still have to perform domestic chores. This empowerment has changed household duty allocation, hence contributing to intra-household gender conflict in a majority of resource-poor household. Earlier studies have also similar patterns in Maragwa district in central province.

Both the rural and the urban setting have been affected by the above phenomenon. Kagio town in Kirinyaga County, in the central province of Kenya is uniquely inclusive of both the urban and the rural population at close proximity. There is a large and fast growing market, which serves as a market for farm produce from the surrounding rural farms. The market attracts traders from different parts of the country, but a large number are those from Nairobi and Mombasa and the surrounding areas of Kerugoya, Baricho, Kutus and Sagana. Bananas, tomatoes and rice are among the leading produce in Kagio market. Due to this feature of trade Kagio has become a hub for settlement of business oriented persons, and a target for many empowerment machineries, especially the financial institutions. Modernity, urbanization and technology are swiftly taking over Kagio town, in central province. A large number of traders in the market are women and they are leading in proprietorship.

\section{Literature Review}

Two categories of writings are examined in this section. First is literature that informs the general understanding of gender relations and liberation initiatives. This includes the history of women liberation movement among other scholarly works. The other part of the literature contains information that informs and supports the theoretical and conceptual frame

\footnotetext{
${ }^{2}$ Agnes P. Zani, The Family in its African Socio-Cultural Context in P.Ryan(Ed), The Model of the Church as Family,(CUEA publications, 1999)pp46-55
} 
work of the study. Ann M. Clifford in her work on Introducing Feminist Theology notes a major historical background to the aspect of feminism/ women liberation. She explains that feminisms owe its history largely to the several waves of feminism that date back to the late $18^{\text {th }}$ century. They include the first wave which originally focused on the promotion of equal contract and property rights for women and the opposition to chattel marriage and ownership of married women (and their children) by their husbands.

The second wave feminism not only revived women's political struggles for civil rights and equal pay, but also brought forth feminist studies as a new academic discipline. Third wave feminism began in the early 1990's, arising as a response to perceived failure of the second wave and also as a response to the backlash against initiatives and movements created by the second wave. The third-wave feminism sought to challenge or avoid what it deemed the second wave's essentialists definitions of femininity, which (according to her over-emphasize the experiences of upper middle-class white women or rather did not regard the issue of contextualization of women sufferings and therefore need for liberation.

It is on the platform of the third wave of feminism that women liberation takes an international dimension, bringing on board international feminism, which is marked by the four United Nations Conferences on women held in Mexico City (1975), Copenhagen (1980) Nairobi (1985) and Beijing (1995) together with the conference on population control in Cairo (1994) debate issues of women equality and well-being. By further elaborating on issues like the why and what of Christian feminist theology, feminist perspectives on the bible, on God, on women and the church and on feminist perspective on ecology, she further enriches the background understanding of women liberation which is crucial to this study. However Clifford's study does not go to the extent of analyzing the impact of women liberation to the Family setting let alone the African Christian Family.

Leonardo Boff and Clodovis Boff, in their work on, Introducing Liberation Theology" articulate that liberation theology is not a confine of a few, that liberation theology happens at three levels, namely; the professional, pastoral and the popular level and provides an insight into new way of doing liberation theology in an inclusive manner, through a living commitment, socio-analytical mediation, hermeneutical mediation and practical mediation. This has informed the manner in which this study will be conducted. Nevertheless their work does not cover the assessment of the impact of these various levels and new way of doing liberation theology to the African Christian family. ${ }^{3}$

P.N. Wachege -discusses the issue of African women liberation from a man's perspective. He describes what women oppression and liberation entails. He says that women oppression is a distorted way of life in which women are dehumanized, marginalized and subjugated by being denied their rights as real persons, being treated and mistreated as inferior beings and deprived of growth into authenticity and self fulfillment. He identifies various forms of oppression which include, Traditional, Social, political, economic, sexual, intellectual and ecclesiastical oppression. He further consider a possible way forward, in which he comes up with a liberation model for the African women with Jesus Christ as the model of liberation therefore establishing an African women liberational Christology.

This is important to this study in the sense that it affirms that indeed women liberation is on going in the African community. Nevertheless, he does not engage in evaluation of the impact of this liberation model to the African Christina family, where the women are the recipient and beneficiary of this initiative belong, a gap that this study seeks to address. Wachege makes contribution to the understanding of the phenomenon of single motherhood. In his work, he identifies various types of single motherhood, triggered by diverse modes of women liberation. This is rather instrumental in informing the thought of this study that indeed there is diverse impact resulting from diverse modes of women liberation. But he does not directly point out the impact of these modes of women liberation to the African Christian families, a subject that this study addresses.

P. Frostine, on an explication of the South African Black theology and theology in the context of Ujamaa, he argues that different situations, of oppression in the era of apartheid and that of the ujamaa system of governance in South African and Tanzania respectively, presented different situations for liberation and therefore demanding different approaches in the liberation initiatives, thus resulting to the Black theology in South Africa which was different in accentuation from that of Tanzania. Frostin, despite this important views which indeed support the fact that different oppressive situation, demand and therefore result to different liberation perspectives does not go to the extent of examining the impact or the result of these liberation perspectives to the people in question and therefore not even to the African Christian family, a dimension that this study seek to address.

E.S. Fiorenza, engages in an inquiry into the links between critical feminist struggles for liberation and well being, emphasizing on an engagement on learning how to read/ understand the bible from the standpoint of a feminist theory of justice and feminist movement for change. She propagates a feminist outlook in understanding the bible with the aim of

${ }^{3}$ L.Boff and C.Boff ., Introducing Liberation Theology, Maryknoll, (New York: Orbis Books, 1987) pp1-19 
liberating the women. ${ }^{4}$ She further identified various modes of feminist trends which include; maternal feminism, complementary feminism, international feminism, post biblical feminism, eco- feminism among others. Her work is instrumental in informing on the modes of feminism/women liberation. She does not engage in an analysis of the impact of these trends of feminism to the African Christian family.

C. Nyamiti, African family ecclesiology, indicates the centrality of the family to the church. He argues that is in the African synod that the concept of church as family evolved. This is important in reinforcing the need to address the issue of the African Christian family. Its sustainability or collapse is central to the existence of the African church. He identifies several challenges, which include the second liberation, war and its consequences, ethnocentrism, poverty, gender oppression and repression. The threat to the family he says; needs to be included as one of those challenges. The challenges on the family are among them, dispersal of family members the generation gap, urbanization, unstable partnership and new forms of family union. Nyamiti does not further discussion the causes of these challenges to the family, a goal that this study seeks to achieve by trying to establish, if indeed such challenges facing the African Christian family could be linked to the phenomenon of women liberation.

Agnes, P.zani, on the family in its socio- cultural contexts, says that the African family has undergone various transformations in structure, form and functioning, resulting into various dimensions to the African family, with distinctive characteristics. These changes have been necessitated by the need to adapt to the changing situation in the African society. Among such situation is the influx of modernity and different religious forms.

A distinctive characteristic of the African family is the existence in composite form, which are plural marriages involving multiple spouses living together in a communal life. The various types of families include polygny and polyandry which are part of the polygamous set up of a family, extended family system and the nuclear family systems.

She clearly notes that the nuclear family has largely gained root in modern African societies and has been described as the smallest and most elementary types of family: this has been due to the pressure of social change caused by industrialization and urbanization. The composite family system has continued to exist but in different forms from that of the African traditional society. Zani's study has been important in informing the understanding of the African family, which is a key subject matter of this study. However, she does not address the possibility of the force of women liberation as one of the challenges or waves prompting change to the African family, a dimension that this study seeks to evaluate.

J.N.K Mugambi in his critique of Bultman's work on demythologization, he argues for Remythologisations. He says that any attempt of demythologization, ends up in destruction of the existing myths and thus creating a new myths. In order not to interfere with the fundamentals of a particular religion or worldview, and ensure its continuity and sustainability, the revision need not be will an aim to destroy the existing perception or rather replacing them with new ones, but we should engage in redoing or vision of those perception in line with our context, but retaining the fundamental principles. ${ }^{5}$ This argument has greatly informed the perception of the study problem. The researcher opines that some modes of women liberation, while liberating the women, have destroyed the essence of femininity and replaced the ideals of a liberated woman with the fundamental capability of the masculine, therefore triggering a problem in gender relations.

Mugambi,s work on the critical examination of the Exodus narrative raises serious questions about the beginning and the end of the exodus process of liberation, from Pharaoh's oppression to the freedom in Canaan. However the exodus narrative does not end with the invasion, siege, conquest and eventual occupation of Canaan. The narrative continues with the former slaves becoming invaders and oppressors of themselves" In an analogy of these situation women liberation has largely concentrated with the emancipation of women from a male dominated and oppressive society/ culture/ theologies, but like the exodus narrative these may not or has not ended with the invasion, siege, conquest and eventual occupation of the male dominated territories. In line with this view, the study seeks to examine and understand; the aftermath of these liberation efforts, In other words the resultant effect of women liberation in African Christian family setting, where one of the partners involved is the woman who is largely impacted upon - by the women liberation efforts. Could the diverse modes of women liberation in addressing gender related disparities have triggered the supposed crises in gender relation in the context of the African Christian families?

\section{Theoretical Framework}

This study was guided by three theories,: Mediation Theory as propagated by Leonardo Boff and Clodovis Boff, Theory of Different Perception of Feminism Resulting in Diverse Modes of Feminism as xplicated by P.N. Wachege, and

${ }^{4}$ E.S. Fiorenza, Wisdom Ways: Introducing Feminist Biblical Interpretation, Maryknoll, (New York, Orbis Books, 2001)pp1ff

5 J.N.K. Mugambi, From Liberation To Reconstruction: African Christian Theology After The Cold War, (Nairobi: E.A.L publishers, 1995) 
Remythologisation and reconstruction as explicated by J.N.K. Mugambi.

According to the Mediation theory, there are four aspects in primary sourcing and writing. The first stage is INSERTION, which enables us to mingle with the people, live with them, talk with them while on the ground, thereby learning to get first hand information concerning the issue of our research problem. The second aspect is SOCIAL ANALYSIS. Here, critical analysis of the assembled data is done, this helps in understanding the impact of some modes of women liberation to the African Christian families in Kagio town in Kirinyaga County. The third aspect is HERMENEUTICAL ANALYSIS. This is concerned with relating insights drawn from the social analysis, tothe will of God which is an exercise in theological reflection, since the centrality and fundamental option of this study is Christian and not merely sociological and anthropological. The fourth aspect is PRAXIS. This involves coming up with the way forward, that is, the practical implication of the study.

According to Wachege's theory, different perceptions have triggered a pluriformity of modes of women liberation. In his book, "Third Millennium African Single Mothers and Mother Widow" in reference to the works of Elisabeth S. Fiorenza, Wachege identifies some modes of women liberation that are gender friendly and others that are gender challenging, for example, Maternal feminism and Complementary feminism, International feminism and Post Biblical feminism respectively. In light of this explication, the study recognizes the need for diversity in outlook while examining/ analyzing the impact of women liberation to gender relations in the African Christian families, in view of the support and challenges.

Finally is the 'Remythologisation theory'. In his critique of Bultman's project of 'demythologisation' Mugambi argues that hermeneutically, myths cannot be abstracted from the gospel. Any attempt to "demythologise" results into new myths. Instead of "demythologise" Mugambi urges for "remythologisation". He says Bultman in his attempt to satisfy scientific positivism by denouncing myths (he) ends up destroying the reality of religion. Critically analzing the exodus motive, it emanates that liberation is a cyclical process. It does not end with the invasion, siege, conquest and eventual occupation of Canaan. The narrative continues with the former slaves becoming invaders and oppressors of themselves.

There is a triangulation of the three theories in this study. Mediation theory informs the process of conducting this study, in the four stages outlined in the theory. The theory of different perception informs the need for objectivity while examining the impact of women liberation to the African Christian family, owing to the existent diverse trends of women liberation. Remythologisation and reconstruction theories,provide a conceptual background of the research problem. It sheds light into the possibility of a new form of oppression born out of the women liberation initiatives, prompting the need to evaluate the impact of women liberation to the African Christian family.

\section{Methodology}

The study is based in Kagio town in Kirinyaga County, in central province of Kenya. The population in Kagio is both urban and rural in nature,. A majority of the population comprises of business people or entrepreneurs, who do not indigenously come from Kagio, but have settled there for business purposes. Kagio market attracts trader from as far as coast province, Nairobi and neighbouring towns and rural farm in Kirinyaga district and central province at large. The resident population is dominantly Christian.

Target samples were subjectively identified by the researcher, depending on their availability to contribute to this study. They were identified from churches, which included; The Presbyterian Church of East Africa (P.C.E.A.) Kagio, The Catholic Church Kagio and the Anglican Church Kagio. Others were approached from social welfare groups "Chamas", organizations like Kenya Women Finance Trust (KWFT), Equity bank and Pamoja Women Development Fund. Individuals were also approached from their business premises in kagio market as well in their farms. Leaders and members of institutions were equally involved.

The study utilized primary sources, secondary sources and experiential knowledge. Secondary data was gathered from monographs, periodicals, academic papers and archival materials found in libraries like Jomo Kenyatta Memorial library in the University of Nairobi, Tangaza College library, Hekima library, P.N. Wachege's little Eden Home library, the department of gender studies archival and both the department of sociology and philosophy and religious studies library at the University of Nairobi. Documents available from the offices and libraries of the Family Life Counseling Association of Kenya along Muchumbi Road in Nairobi, Family Life Promotion and Service Centre, Council for Economic Empowerment of Women were examined.

\section{The African Family}

This institution which is largely in recognition of the extended family ties and relations has undergone various transformations in structure and functioning. Nevertheless the values and ideals of an African family from the African 
traditional perspective are still at large. There are various elements central to the African worldview and African family. These include; the element of community, which is seen especially through the emphasis upon relations within the extended family context. Africans find their identity and meaning of life through extended family ties. There is a strong feeling of common participation in life, a common history and a common destiny. This is also echoed in the words and writings of J. S Mbiti that "I am, because we are and we are because I am".

Second, is the element of ancestorship. Emphasis is on existence, relationship and place of ancestors in the African family cycle. Ancestors are mainly considered as an important mediation between the life here and life thereafter; between the spiritual and the physical. The third is the element of vital force. Fourth is the emphasis on prioritizing people and human relationships as opposed to technology and material things, fifth, the existence of colonial rule and experience of independence which is largely part of the African history and experiences. Sixth is the continued quest for liberation, seventh is, a wholistic outlook to life, such that family life is not separate from working life and neither is it distinct from their spiritual life and praxis. This is to mean that for Africans, aspects of life are interwoven and not compartmentalized. Eighth, emphasis on events of life more than emphasis on schedule and time as it is in the western culture. It is from these elements that the African family orientation is largely informed. It is important to note that, the level and commitment with which different communities emphasize on this outlook of life may differ. In view of diversity of the African communities, the researcher subjectively chose to study the Agikuyu community family life for a deeper and more authentic understanding of the African family and way of life.

Kinship ties and the institutionalized family is a fundamental unit upon which the life of the Agikuyu was defined. It is around kinship, that social and economic activities were largely built6. The myth of the origin of the Agikuyu itself is explained through a family setting, without which they would perhaps not be in existence. The persons of Gikuyu and his wife Mumbi, are said to have been given power by 'Ngai' or 'Mogai' their god and given the mandate to procreate, therefore an element of continuity. They bore ten daughters, but as it was made clear by my respondents, only nine are normally recognized, because the tenth one did not get married. Instead she got pregnant while at home, what was referred to as "ihu ria riikoini"". This aspect, emphases the marriage experience.

The nine daughters are said to have gotten married to very handsome men and their families formed the nine clans of the Agikuyu; 'Ambui' whose mother is Wambui, 'Angui also known as Aithiegeni' whose mother is Wangui also known as Waithiegeni, Angari clan also known as Aithekahuno, whose mother is Wangari, Akiuru also known as the Abura or Ethaga clan whose mother is Wambura also known as Wakiuru or Nyambura, Agaciku clan whose mother is Wanjiku, the Airimu or Athigia clan whose mother is Wairimu also known as Gathigia, Anjiru clan whose mother is Wanjiru, the Angeci or Aithirandu clan whose mother is Wangeci also known as Waithira, and finally the Aicakamuyu clan whose mother is Wamuyu, the daughter who never got married, but had a child at her maternal home. To date,the Agikuyu community is organized in this clans, though the emphasis on the family name 'mbari, is predominant with increased emphasis on the nuclear family over extended relations.

\subsection{Relational and Role Definition}

The Agikuyu community is patriarchal. Marriage was based on mutual love and gratification of sexual instincts between the two people involved. The family constituted a permanent union between one man and one woman or several women. The man acquired sole conjugal rights within the woman or women whom he married. Marriage was not considered a personal affair, especially after signing and sealing the marriage contract. It was an affair of the wider community and particularly both extended families involved. This was displayed through the active role and participation of grandparents in the upbringing of their children, participation of the uncles and aunties in the lives of the children through various initiation stages among other communal aspects of family and marriage life.

The men were mandated to protect their community and families, regardless of whether they had been initiated into warriorhood or not. The duty of fending for the family was considered a collective responsibility, through division of labour. For instance, the weeding of the land in preparation for planting was mainly a man's responsibility, since they were considered physically stronger and resilient. Both the men and women participated in digging /ploughing the land in readiness for planting. Women and children planted the seeds. Although all people were involved in harvesting, more often women managed the harvested proceeds and ensured there was enough to feed the household till the next harvest. Children were expected to participate in the economic activities, domestic chores and also in the social and religious activities of the community. 


\title{
5.2 Centrality
}

The origin and being of the Agikuyu people is traced to the family setting. Perhaps, without the marriage and family background, there would be no Agikuyu community. Marriage among the Agikuyu was a significant and central instrument of continuity. It was viewed as a social and also a sacred duty whose desire for fulfillment was deeply rooted in the lives of both the man and the woman ${ }^{8}$. Marriage was also considered as one of the most powerful means of maintaining the cohesion of the Agikuyu community and key institution for enforcing conformity to the kinship system and the tribal organization, without which social life was impossible.

The researcher opines that, without the existence of the family even the very religion of the Africa people would not be realized. The social and spiritual centrality of the family can best be articulated through an examination of the initiation processes of the community. Foremost was the birth rite, which mainly involved the birthing processes and the naming of the child. This was important in giving or forming the identity of the child and incorporating the child into the community. It was considered crucial in ensuring continuity of the given clan and family name. Then the children would go through an initiation process of transmission of values and acquisition of the knowledge of their community. This was done mainly by the grandparents, in the evening as they sat round the fireplace. The learning process was largely carried out through oral narratives, myths and proverbs. Understanding of the community way of life was also through active participation of children in. rituals, economic activities and other social functions.

The formative stage was considered very crucial. It is at this stage also that relationships were defined. For example, relating with the elders, the opposite gender and even one's peers. At puberty, the teenagers would undergo the initiation rite of circumcision, which marked the transition from childhood to adulthood. The initiates were given an identity with an age group which was considered a crucial mark of solidarity and identity and helped in keeping one's life in check, morally, social, spiritually, simply in all aspects of one's life. There was also instruction on what is expected of an adult in the community. After successful initiation into adulthood some men would be initiated as warriors, but all were considered to be ready for marriage. The significance and emphasis on marriage is being handled in this chapter. Marriage was the followed by the initiation rite into elder hood and then ancestorhood for those who departed into the afterlife. It is important to note that, not just anyone qualified to be an elder or an ancestor in the community, several factors were put into consideration in order for one to qualify for this initiation rites.

The importance of existence and stability of the family among the Agikuyu and therefore the African community cannot be overemphasized. It is an important pillar of society, in ensuring continuity, socialization, economic development, spiritual experience and a wholistic development of an individual and the society.

\section{Christian family}

God observed that it is not good for a man to be alone, leading to the creation of a helper corresponding to him. This woman is not created from the earth, but from the man's own self, the woman is fashioned. This perhaps explains the existent sexual attraction and the inherent need for a man to live and belong with a woman and vice versa. ${ }^{9}$ According to the creation myth in the book of Genesis, marriage is instituted by God in the Garden of Eden.

\begin{abstract}
"And the Lord God caused a deep sleep to fall upon Adam and he slept; and he took one of his ribs, which the Lord God had taken, from man, made him a woman and brought her to the man. And Adam said, this is now bone of my bones, and flesh of my flesh, she shall be called woman, because she was taken out of man. Therefore, shall a man leave his father and mother and shall cleave to his wife and they shall be one flesh. And they were both naked, the man and his wife and were not ashamed"
\end{abstract}

In the Gospels, the origin of marriage and therefore family is articulated in the book of Matthew and that of St. Mark.

\footnotetext{
"And he answered and said unto them, have ye not read, that which made (them) at the beginning made then male and female, and said, for this cause shall a man leave father and mother, and shall cleave to his wife and they twain, but one flesh. What therefore God has joined together no man put asunder.
}

After their creation, man and woman, are given the command and blessing to be fruitful and subdue the earth or

\footnotetext{
${ }^{8} \mathrm{lbid}$.

${ }^{9}$ Genesis 2:18.
} 
rather master the earth. Of importance to this study is the aspect of fruitfulness, which is seen clearly when the humanity is receiving punishment for the fall into sin. The woman, whom child bearing is a constituent part of her nature will attend child bearing with great pain.

\subsection{Relational and role definition}

The Christian, marriage is between a male and female. The union is permanent in nature and that's why the issue of divorce is largely opposed in the biblical teachings. For example, Jesus' teaching on marriage and divorce, is that the married couple are one flesh, and therefore their relationship cannot be dissolved, though some New Testament passages like, Matt 5:32, 19:9, $1^{\text {st }}$ Corinthians 7:10-16 are seen to provide for some exception to the absolute teaching of Jesus. Jesus regards the teaching in Deuteronomy 24:1-4, which allowed divorce, as a concession to human weakness and a dispensation form the original plan of God for marriage. Jesus quotes Genesis 1:27; 2:24, asserting God's original plan for marriage and therefore his position against divorce, qualifying marriage as a permanent union.

According to the doctrine in Ephesians, wives are to submit to their husbands, as to the Lord, the husband are to be the head of their wives in view of Christ headship and love for his body. The church serves as a perfect model of submission to Christ, it also serves as a model for wives submission to their husbands. As Christ sacrificially loved the church and gave himself up for her, so are husbands expected to love their wives. They ought to love their wives as their own bodies. Children should obey their parents in the Lord, for it is right to do so. They are supposed to honour their fathers and mothers and this is said to be the first command with a promise. Fathers are to carry out the duty of bringing up their children while training and instructing them in the instructions of Christ. ${ }^{10}$ There is an exhortation to fathers to provide for their children.

Fidelity also defines relationship in the Christian's life and marriage. An analogy of refreshing and life giving water, which is to be guarded and never shared with strangers is used to emphasize the need for fidelity and the joy and fulfillment expected of sexual union in marriage. In reference to the $1^{\text {st }}$ letter to the Corinthians, the husband is expected to fulfill his marital duty to his wife, and likewise the wife to her husband. The wife's body is said not to belong to her alone, but her husband is entitled as well. Similarly the husband body does not belong to him, but to the wife as well. The couple is expected not to deprive each other except with mutual concept and only for a time.

Marriage to non-believer should not be dissolved especially if the non-believing spouse is willing to live with the believer. But if the non-believing party leaves they are to be let to do so. An example of a woman of noble character is provided, indicating that women can be up to task in their various roles. She is full of wisdom, of great value to her husband, engages in ceaseless extraordinary activities, engages in commercial dealings, she is alluded to wealth and nobility, the woman fears the Lord and is to be praised.

\subsection{Centrality of the family to Christian faith and teaching}

Foremost the participation of Jesus Christ at the wedding at the Cana of Galilee where he performs his first miracle, affirms the significant position of marriage in Christian lives.

The importance of marriage in expressing the gospel truths cannot be ignored. The use of the family and marriage analogies to express/describe the relationship between Christ and the church or the earthly and the heavenly kingdom only further articulates the centrality of marriage and family to the Christian church and the Christian faith. For example, the illustration in the book Hosea of the marriage experience of the prophet is used to pass a message to the children of Israel, of the personal love that God has for his people, despite their gross failing. Though they have engaged in harlotry or adultery in their expected otherwise faithful relationship with God, God is faithful and abiding to his covenant of love and is willing to forgive and save them, if they just truly repent.

Second, the allegory of the unfaithful Jerusalem used by the prophet Ezekiel, is used to rebuke and remind the Israelites of their unfaithfulness in their relationship to God and the need for their repentance, is also centered on the family setting/structure. Mention of such as birth of a child, reference to sons and daughters, reference to Israel as an adulterous wife, all ascertain the centrality of the family to the Christian teaching. The expressions in the book of songs of songs are also a good example of the use of erotic love or relations, to express truths about the word of God and the approval of such relationships.

Paul uses the analogy of marriage to explain important truths, about the kingdom of Christ, talking about the law and the freedom in Christ. He argues that the law has authority over a man only as long as he lives, giving an example

${ }^{10}$ Ephesians 5: 22ff, Ephesians 6: 1-9 
that; by law a married woman is bound to her husband as long as he is alive, but if her husband dies, she is released from the law of marriage, and if she marries another man while her husband is still alive, she is called an adulteress. He further argues, that a Christian is like this wife whose husband had died, therefore through death of Christ and resurrection the Christian is freed from the law.

Similarly, the Old and New Testament repeatedly uses the analogies of father-son relationship as well as marriage relationship to express the relationship of God to his people and Christ to his church. Attitudes that emerge clearly in these relationships are related to love, devotion, and obedience and are central to the doctrines and teachings in Christianity. With the absence of marriage and family, the idea of Christ as the bride and church as the groom and several other articulation presented above, would be so foreign to the Christ faith. How would it be like to be called a child of God, or even to identify with God as father, Or church as family of God, without the experience of one?

Marriage and family are essential in ensuring the very existences and continuity of the human race. The command in the book of Genesis, for man to multiply and subdue the earth, and all that is in it, adds to the emphasis. Though the church and Christian teachings outline the ethical and moral conduct appropriate for individuals in the society, the check and balances on the same, are more effective in a family setting, which is a primary and main institution of socialization.

\section{The African Christian family}

The understanding of the African Christian Family is in view of one of the fundamental orientation of African Christian theology (A.C.T.) inculturation. It is largely a constituent of the African Christian traditions and in the contemporary situation, the secular ideologies serve as an influence as well.

\subsection{Origin and continuity}

Both the African orientation and the Christian orientation share or trace an origin to a supreme and divine transcendental power referred to as, God or 'Yahweh' by the Christians and 'Ngai' or "Mogai" for the Agikuyu. Similarly in both orientations, people or human creation is used by the supernatural to ensure growth and continuity of the human race and in both cases, through a marital union, of a husband and wife; Gikuyu and Mumbi his wife, Adam and Eve his wife. The element of procreation is present in both traditions to ensure growth and continuity of the human race. The nine daughters of Gikuyu and Mumbi who get married to handsome men and in turn give rise to the nine clans of the Agikuyu which many of the Agikuyu people identify with, regardless of their Christina faith. The Christian teaching identify all as children of God, though not born of natural descent, but through adoption. This is not to say that the element of natural birth is not emphasized, rather it is widely present throughout the bible and is one of the primary goals of a marriage union, amongst Christian couples.

The contemporary phenomenons, have influenced the nature of the African Christian family. Science has largely been sort to explain the origin of humanity. Technologies such as test tube babies, surrogate mothers, have compromised the ideal of procreation through physical sexual contact between a male and a female. Ideologies of individualism have promoted such as, preference for single parenthood and increasing approval of the same in the society. Growth and continuity of the human race is not necessarily propagated through an ideal marital union, despite the individuals involved subscribing to the African orientation by virtue of racially being so or ascribing to the Christian faith and teaching.

\subsection{Relational and role definition}

In both African and Christian traditions, the relationship between a husband and a wife is based on an erotic love relationship, though Christianity emphasizes the agape love in addition to the erotic relationship between the spouses. In the African traditional context, polygamy is allowed, while in Christianity monogamy is emphasized. In both orientations, there is a hierarchical dimension to the nature of relationship in marriage and therefore family setting. A husband is considered head of the household while the wife is his subordinate. In the Christian teaching, there is a clear cut emphasis for the husband to love his wife in the model of Christ's love for his church and in turn the wife is to submit. In the African tradition submission of the wife is demanded, though there is no definite requirement for the husband to love his wife or wives, as it is described in Christianity. More often than not, the woman is regarded as 'chattel' i.e. the man's property together with whatever else he owns.

Fidelity is highly emphasized both in the Christian and African traditions. In Christianity, both the male and female are required to uphold sexual purity in their marital union. In the African context, the emphasis is directed to the woman, 
with no categorical demand or lack of to the man.Divorce is forbidden in the Christian tradition, and only one exception is made, which is in the case of infidelity. Even so, freedom to marry another is not permitted, essentially implying that the existent marital union still abounds, despite the separation. Only death of a spouse can annul a marital union. In the African tradition, divorce is opposed though not with much emphasis as in the Christian teaching. There is permissiveness for divorce, under various circumstances, like infidelity, bareness, and in the case of being cursed in one way or the other.

In the African tradition family/marriages, the duty of fending for the family or bread winning is a shared responsibility and not solely left to the man. The wife manages the harvest, ensuring that the family's fed from one harvest season through to the other. The Christian teaching categorically states that a man is expected to be the bread winner, though an exception is the book of proverbs 31:10. In the Christian family, the father/husband is equated to a priest. He has a duty to lead his family in fellowship and stewardship in view of the Christian teachings and doctrines. In the African tradition, the spiritual matter and guidance on them, is largely at a community level and led and conducted by designated people.

In both the African and Christian traditions children are expected to receive instructions and obey their parents. Rewards and punishments are encouraged as a means of instilling values and eliminating bad behaviour in children. Nevertheless, the aspect of socialization into the community's way of life is more emphatic and clearly organized in the African traditional setting, as compared to the Christian family setting. Churches and family are expected to design their own, programmes of socializing into the Christian way of life. The success and failures need be check, since the processes are not as natural as those in the African traditional society.

The contemporary African Christian Family shares selectively the African family orientation as well as the Christian orientation but is also subject to the influence modernity and secularism. For instance, it is not uncommon to find an African Christian couple, who equally share in the responsibility of providing for the household as well in the domestic chores. It is not unusual either to find an African Christian couple, where the woman basically runs the home, by virtue that they have more resources at their disposal and their husbands not gainfully engaged financially. In other cases the woman assumes both the father and mother responsibility in cases of long distant marriage. Role division is gradually losing its dichotomization, with lots of resultant negative and positive repercussions.

Divorce is being accommodated gradually amongst the Christian faithful, especially with increasing challenges and threats to the marital institutions. Parental responsibility can be said to have suffered most in the contemporary situations, with both the male and female spouses away to work and the duty of parenting left to hired house helps/nannies. The feature of community involvement in parenting is nearly impossible, with some children growing up without getting to meet or know any of their extended family members. Polygamous union is outlawed in the Christian circles. Nevertheless, infidelity is high ranking among the challenges facing the marriage institutions in the contemporary African setting. Value transmission has seriously been distorted within the African Christian family in the contemporary society. Absentee parents, limited attendance of church programmes, non involvement of extended relations in upbringing of children, replacement of the communal approach of life with individualism, and extensive exposure to the mass media are some of the factors that hinder adequate or proper value transmission.

\section{The Women Liberation Movement}

\subsection{History of Women Liberation}

The women movement, otherwise known as "women liberation" or "feminist movement" began in the western world in the late $18^{\text {th }}$ century and has gone through various metamorphological stages to what it is in African society today. It was marked by an extended period of feminist activity between nineteenth and twentieth centuries in the United Kingdom and United States. The original focus was on promotion of equal contracts and property rights for women and the opposition to Chattel marriage and ownership of married women (and their children) by their husband. But by the end of the nineteen century, activism was basically focused on gaining political power, though sexual, reproductive and economic rights for woman were still being advocated for.

Feminists or women liberation front took another dimension, while still propagating for the above rights. There was an emphasis on ending discrimination in view of culture and political inequalities. Women were encouraged to view aspects of their personal lives as deeply politicized and as reflecting sexist power structures. Then a different dimension to the women liberation movement took center stage as from early 1990's. The perception was that earlier paradigm had failed and therefore the emphasis on post structuralist interpretation of gender and sexuality. The metamorphological journey continued with various debates emanating, leading to the birth of different categories of feminism, herein referring 
to E.S Fiorenza's categorization, which deems rather exhaustive to the researcher. The modes of feminism include: Complementary feminism, Gynecentric/ radical feminism, Lesbian feminism, Gender feminism/ difference feminism, maternal feminism, eco-feminism, post-modern feminism, third world feminism, contextual feminism, global feminism/ post-colonial feminism, international feminism, religious feminism, post Biblical feminism and critical liberationist feminism.

The women liberation movement and ideologies into Africa and therefore Kenya can largely be attributed to the United Nation (UN) World Conference on women. The first conference held in Mexico City in 1975, was marked by different concerns reflecting political and economic relations of the time. Women from the East emphasized on peace, from the west on equity and developing nation like Kenya on development. It is important to note that by the end of the conference, development which was a primary concern for the women from developing nations, was now considered as a most important means for furthering equality of the sexes and the maintenance of peace. The pure concern for development by women from the developing nations is no longer a primary agenda. These women went back home with information that something is wrong with gender relations, and therefore as much as there is need to propagate development, it is essential to do it in view of sexism. The Mexico conference resulted into the adoption of a convention, on the "Elimination of all forms of discrimination against women" one of the most powerful instruments for women equality in 1979, now dubbed "the bill of rights for women.

The Copenhagen conference followed in 1980. The concerns of disparity between rights secured and women's ability to exercise the rights, emerged. Albeit not by consensus, the various factors for the discrepancy were outlined and a programme of action was laid down. This called for stronger national measures to ensure women's rights to inheritance, child custody and loss of nationality. The third conference was held in Nairobi in 1985. Participants were especially vocal on violence against women, which was felt not to have been given due attention, But others believed that the focus needed be on finding ways to strengthen the role of women in peace and development initiatives. Participants came to a consensus of, considering all the issues as of equal importance.

The conference in Beijing in 1995, had the main themes as; the advancement and empowerment of women in relation to women's human rights, women and poverty, women and decision making, the girl child, violence against women and other concerns. Governments and the UN agreed to promote the gender mainstreaming in policies and programmes as a result. Active Women liberation movement and its agenda took root in the Kenyan society largely after the participation in the UN conferences on women. various debates emerged, leading to different trends in women liberation. While examining the nature of the UN conferences and their agenda, some critical questions herein arise. First, was women oppression and liberation as described today a concern of the African women from the onset of it all? If yes, were the solutions accorded in response or recognition of the need, aspiration and thought forms of the African women? Do women in the developed nations and other stakeholders propagating the women movement agendas really identify with the suffering of the African woman or are they oppressors and beneficiaries of the oppression of the African women and that or the African people in general?

\subsection{Initiatives Identified with Women Empowerment}

More than a few of the respondents identified various church groups as a major source of support or channel for women empowerment. Financial institution mainly geared towards support of women and others running programmes specifically addressing women needs amidst providing financial services for their male counter parts were also identified. Health institutions also emerged as channel for women empowerment and liberation. Those identified include such as:-

\subsection{The Catholic Women Association (CWA)}

This is a group of women in the Roman Catholic Church (R.C.C) in Kagio. It is generally concerned with lay apostolate among women. Its formation dates back to December 1966, when a group of Catholic women, from various lay organizations such as catholic action, the legion of Mary, the young children student among others, met in Gitooro, Meru to share ideas about their organizations and lay apostolate among women. As a result of the meeting a decision was arrived upon to establish an umbrella or common organization to facilitate the activities of women in the Catholic Church on a national basis and thus the formation of the Kenya National Council of Women (NCCW). The constitution of NCCW was ratified by the Episcopal conference in 1967. The NCCW now has branches which are then referred to as the catholic women's associations, which are all over the country and thus CWA in Kagio.

The CWA is guided by the NCCW's constitution but groups such as the diocesan and parochial have fairly some freedom to interprets and actualize the laid down roles, objectives and other specifications depending on their context but 
in consultation with the relevant church authorities. The main objectives guiding the activities of the CWA stated in the NCCW constitution Kenyan chapter and therefore Kagio CWA includes:-

- To foster the spiritual growth of the members in keeping with its motto "strong faith".

- To help members become better people in their roles as wives, professionals, mothers and citizens.

- To assist in evangelism.

- To give catholic women in Kenya a voice through which their views can be heard in national and international affairs.

- To train leadership

- To help members become self reliant

- To assist the needy in society

- To help sensitize women on important topical issues.

In line with the NCCW main objectives the specific activities carried out by the CWA Kagio include, the observance of the two most important feasts in the liturgical calendar, which include the feast of the annunciation and the feast of St. Monica. They also organize forums for discussions of issues such as parenting, marriage, bible study and other issues of concern to women's life. There is also visitation ministry for the sick, bereaved or needy. There is a financial support kitty to which every member contributes for the purpose of supporting those faced with various challenges such as sickness, bereavement or those with celebration like weddings. In addition the contribution and support in kind, they are also very actively involved in person, in various activities of their members such as, wedding and burials. They meet every third Sunday of the month after mass for spiritual nourishment and discuss matters pertaining to the group's welfare. The group provides immense social support to the members.

\subsection{The Mothers Union}

The mothers union is a Christian Organization of the Anglican communion, which has spread to many parts of the world. It was founded in 1876 by an English woman, Mary summer, who when her first child was born, was overwhelmed by what she saw as the awesome responsibility of parents, not only in caring for their children but also for their spiritual nurturing and growth. The mothers union in Kenya was started by European ladies who had accompanied their husbands when they came as settlers, government officials or as church leaders.

The mothers union in Kenya is represented in 29 dioceses of the Anglican church of Kenya. It has a national office which coordinates activities for all its members' nationwide. Each diocese has a committee. Membership to this group is open to all who have been baptized in the name of the Holy Trinity and who declare their support for the aims and objectives of the society. The aim of the mothers' union is the advancement of the Christian religion in the sphere of marriage and family life. It is concerned with all that strengthens and preserves marriage and Christian family life.

The main objectives include:-

i) To uphold Christ teaching on the nature of marriage and to promote its wider understanding.

ii) To encourage parents to bring up their children in the faith and life of the church.

iii) To maintain a worldwide fellowship of Christians united in prayers worship and service.

iv) To promote conditions in society favourable to stable family life and the protection of children.

v) To help those whose family life has met with adversity

The members are required to adhere to the following promise

(i) Confess the faith of Christ crucified and to continue to be his faithful solder and servant to one's life end.

(ii) To uphold and support the objects of the mothers union by word and action.

(iii) To try to plan one's life to include worship in church prayers and bible teaching.

The mothers union engages in several activities in order to realize their laid out goals and objectives. These activities include:-

Holding seminars and training sessions, especially on subjects concerning the family, example parenting, being a good wife, communication, and handling of finances among other pastoral concerns. They are also aggressively involved in marriage preparation sessions in order to help in spreading a greater understanding of marriage in the church. They engage in activities such as visitation of each other in the group in fellowship as well as visiting the needy for prayers and financial support.

The members of the mothers union have also engaged in self help support groups, engaging in small scale projects, where they generate some income to support their members financially and also enable smooth running of the 
group's activities. They also engage in counseling services for families in turmoil or various life crises especially through their leaders.

\subsection{The Women Guild}

The guild is a Christian women group of the Presbyterian Church which traces its origin to the arrival of women missionaries in 1922 after the establishment of the Presbyterian Church in Kenya. There was a need to start a fellowship of girls. 'Girls guild' was started for girls in boarding schools in "Mambere" Thogoto and Tumutumu. They were involved in activities such as, prayer, studying God's word, learning how to live as Christian girls and serve in the kingdom of God. Members, were to be of high moral standards, faithful, hardworking, temperate and of high integrity. Later there was born an initiative referred to as "Movement of the shield" (Kiama Kia Ngo), which was in response against the female genital mutilation (FGM). In 1939, the late Rev. Charles Muhoro Kareri returned to Kenya after his studies and shared with the Christian women the idea of the women guild from South Africa and they enthusiastically embraced it. With the Christian women what he had seen from the women abroad who had a movement they called woman's guild and the enthusiastically embraced the ideas. ${ }^{11}$

It is important to note that though each congregational guild is independent in its activities, it is still largely influenced by the chain of activities defined at the national level organization of the group, and every single running event at the national level, has some contributions or aspect of involvement by the grassroots members. For instance in the national guild project of purchasing a piece of land at Ruiru for future development purposes of the guild project, every woman or member of the guild on the grass root is required to raise an amount of one hundred shillings.

The woman guild today has its membership approximately at 62,000 women. The central committee is the major decision making body and is made up of three officials from all the Presbyterian councils and the regional organizers. The principal shalom girls training centre, the manager woget centre, and retired organizers are ex-officials. The moderator of the general assembly is the chaplain to the central committee. There are various national projects which the woman guild runs. They include PCEA shalom girls training centre, which was founded on a need to empower girls through education and skills training so that they can be self reliant and responsible members of the society. The woman's Guild also runs an ecumenical and training central hotel (woget) in Mombasa, where each member on the grassroots level was to contribute $(100 /=)$ for this project and they did so. Woman guild also actively participates in ecumenical forums both internationally and locally. Some of this include:-

- The world day of prayer

- The international fellowship of the last coin

- The world alliance of reformed churches

- The world council of churches

- The all African conference of churches

- The national council of churches of Kenya

The participation in these forums provides learning opportunities and interaction that enhances the work of the woman's guild. The woman guild also runs sponsorship program to the needy students for secondary school and tertiary institutions depending on availability of funds. They also assist in paying school fees for children of a deceased church minister. The woman guild in Kagio actively participates in national activities through their leaders. They also engage in other activities like seminars, fellowship, prayers, visitation among other church activities.

\subsection{Financial Institutions}

The presence of groups such as Kenya women finance trust (KWFT), Faulu Kenya, Pamoja women development Fund (PAWDEP), Equity bank was highly acknowledged by the respondents. These were identified as main machineries of the economic and financial empowerment of the women. They offer various lending programs on both small and large scale levels. Various financial successes of women and their families were attributed to them as well as some challenges facing the women and the families at large. ${ }^{12}$

\footnotetext{
11 Focus group discussion. Women's Guild March 22nd 2012.

12 Aron wambungu of Equity bank and respondents through questionnaires.
} 


\subsection{Health Facilities}

Through activism on betterment of the maternal and child health, hospital such as Kerugoya general hospital, have gone a long way towards provision of better and affordable services, especially those geared towards the health of the women and the children. There is easier and better access to maternity services, post and pre natal health care, family planning programs as well as services on general health. Guided by the nature of their activities, goals or purposes the common type of women liberation in Kagio, can be viewed under the following categories:-

\subsubsection{Maternal Feminism}

It promotes all the virtues of nurturing preservation, growth, acceptance and pacifism developed through child care and mothering. Maternal feminism challenges autonomous individualism with a virtue ethics and politics based on the relational capabilities cultivated and expressed in the private sphere. Maternal thinking is available to all women whether they are mother or not. It is a residual power accruing from women capacity to bear and nurture children.

This is evident through the supportive activities of the mothers union, the CWA and the women's guild such as seminars and counseling programs on family wellbeing, empowerment of the women to become better mothers and wives and through the charity work of sponsoring the orphaned children in their areas. Other contributors to this line of feminism are the health service providers, like the Kerugoya general hospital which has a maternity wing endeared towards providing cheap almost free maternal health services.

\subsubsection{Complementary Feminism}

This assumes that women and men have essentially different natures. Like two halves of an apple, masculinity and femininity complement each other to make a whole in which the female is either the "deficient" or the "better" half Masculine - feminine dualism is here seen not as oppositional but as corresponding and mutually balancing.

Similarly the churches in Kagio, generally support the kind of feminism through the affirmation of marriage union between the male and the female and the initiatives to promote its sustainability like the pre - marital counseling, teaching on family issues by the church and the woman's group.

\subsubsection{Marxists/ Materialistic Feminism}

It seeks to describe the material basis of women's subjugation and the relationships between the modes of production and wo/mens status. It argues that an analysis of wo/mens oppression must include both reproduction and production. The liberation of wo/men is possible only in and through an egalitarian reordering of productive and reproductive labour in which economic and cultural structure of oppression is dismantled.

The endeavours of the Marxists/ materialistic feminism are mainly realized through the activity of the financial institution geared towards women empowerment in the areas. These institutions include: - KWFT, PAWDEP, FAULU KENYA, EQUITY BANK among other self help group. These categories of feminism may not entirely cover the various initiatives present in Kagio, that are geared towards women liberation but they largely do so.

Some similarity can be identified in regard to this woman liberalization/ empowerment activities. They are largely women only activities and do not enlist male counterpart in activities of the groups.

Largely, activities are defined from a national perspective, more often than not they are not necessarily implemented in a contextual manner. These activities are geared toward emancipation of women and helping then to realize a more authentic kind of living, the nale counterpart are not necessarily exposed to the, expected changes on the women in their lives and in the society.

For the financial institutions, more than a few of the respondent complained of largely no success with the money lent to then, attributing it to either lack of adequate financial management information or reasons they cannot explain, but leading to inability to service the loans and eventually, more often than not, auctioning of their household properties, leading to disputes with their spouses/ partners.

More than a few of the male counterparts viewed this women support machinery with prejudice. They were viewed as dens of gossips, propagating infidelity and marriage breakdowns. It was felt that, the married women were being elusively misled by their single women/ parents counterparts. These empowerment structures were also considered as promoting strife and hatred among community members, since when one is unable to service their loans for instance, the gossip is widespread and the people who lead the auctioning of the defaulters properties are the same people with whom 
they belonged to the same empowerment group and are either neighbours at home, in the market place or colleagues at place of work.

The assertiveness and freedom promoted by the various empowerment machinery, ranging from ability to determine how many children and when to get them through various family planning programs, financial independence, social welfare, marital counseling, among others, have largely promoted better living standards. For instance, the beneficiaries claim that they are better able to meet the needs of the regulated number of children, education wise, and health wise.

\section{Trends In The Contemporary African Christian Family}

\subsection{Trends}

The dominant type of family in Kagio is the nuclear and involves a husband, wife and their child or children. Largely, these families ascribe to both Christian and African family values. The households are pre-dominantly comprised of middle aged persons, between the ages of 18-45 years. The average number of children in these households is 3 . There are also some formally recognized polygamous families and those of single parent and which ascribe to the African and Christian value as well.

Several traits were identified that define the relationship, form and structure of the African Christian family setting in Kagio in Kirinyaga County. These traits are triggered by different situations as shall be discussed below.

\subsection{Ideal Contemporary phenomenon}

This family is marked by a largely harmonious and stable relationship between the spouses and also with their children. In these families spouses are exclusively supportive of one another. The values of open communication, honesty and trust are central to these relationships. Men in this marital relations display an exemplary understanding and acknowledgement of the fact that indeed the status and position of women in the society has changed and these women include their wives. It is not and has not been easy to embrace these realities, necessarily adjust and ensure continued harmonious living with their wives and other women around them. The success has come about with the help of their spouses who have gradually and exclusively involved them through every step of the metamophological process of liberation and transformation. For instance if their wives are involved in any women group, they are constantly informed of the undertaking of the groups and involved in decision making through shared wisdom so as to embrace the offers not only for the good of the woman but for the family at large. The husbands acknowledge and appreciate the help and benefits realized from the various empowerment machineries their wives are involved in. At times they go to the extent of complementing and supporting them in their endeavors. Example if the wives had borrowed some money from a financial support group, given that it was in the full knowledge and consent of their spouse and they are unable to service the loan at a given time, the husband comes in and accords the needed help. Noted is also the aspect of belonging as couples to support groups that are of supportive value to the family. These include couples groups in the churches, in the neighborhoods and other family support groups. The wives in this kind of family setting likewise acknowledge the immense involvement and support of their spouses in their undertakings. They also emphasize on the need for open communication especially about what is considered "women business" in the society. This helps to avoid mistrust, skepticism and many other problems that arise from exclusive individualism and a "mind your own business attitude" .These families have their own share of challenges, and have been able to corporately handle. Thanks to their wellestablished support systems with and without the family.

\subsection{Secret affair and no string attached relationships}

This is a trend that was widely observed among the African Christian Families in kagio. In this case the husband or the wife or both have partners outside their marital union, with whom they are intimately involved.. These relationships are rather guarded secretively, especially from their spouses and are locally identified as "mpango wa kando". The partners outside marriages are seen to serve various needs and particularly those lacking in their marriage relationships. Some equate these relationships to sedatives. Something to help them forget or pacify the stressful situation they could be facing in their marital institutions and not necessarily solving it. There are various reasons that were identified that explain the nature of this relationship. First, having been married in holy matrimony poses a great shame if infidelity is discovered and therefore the secrecy and non-commitment in the relationship. Secrecy is highly regarded by those who dearly love 
their children and cannot stand causing them the pain and psychological trauma that comes with family breakdown, despite challenges with their spouses that could have triggered their involvement in an extra marital affair. Others do love their spouses so much and cannot afford losing them just because they lack in a particular way. Therefore they seek to fill in the missing gap elsewhere without interruption of their marital relationship.

\subsection{Woman Friend cum Substitute Husband Phenomenon}

In this phenomenon a married woman is involved with another woman. More often than not the suitable partner is divorced or separated and they consider them to be very close friends. In some cases the friendship is described as that of business partners. This friendship is so intense, to an extent that the husband and other people around them have a notion that the woman friend has indeed taken the place of the husband. This is because most of their time is spent together and sometimes even away from home. The excuse is mainly on a business meeting, business trip or a "women get away". Interesting is the fact that, even when there is a social function to be attended in the neighborhood or at home or among the family, the married woman will rarely be in the company of their husbands. Sometimes they even attend or organize family functions without informing their spouses. This greatly affects gender relation in the marriage relationships.

\subsection{Absentee Wives/ Mothers Phenomenon}

The study purposively inclines to the observation of the situation of the absentee wives/ mother living out the element if the absentee husbands/ father purely because of the inclination of the study. Largely the societal expectation is that a mother unless departed from the earthly life should be always at home to see their children grow up. The phenomenon of mothers being away from home while their children grow up is relatively new, especially in the African society and has not been readily accepted. This phenomenon involves a wide range of situations; among them is the phenomenon discussed earlier in the category of woman friend/ husband substitute phenomenon, career implication, academic pursuit among other factors. These women are never home for their husband and children.

\subsection{Absentee Parents Phenomenon}

For various reasons, parents are increasingly becoming absent from their home and hence their children. In some cases they are engaged in occupations that do not allow for the parent to be home for a larger part of the growing up of children and their marital life as well. A common situation is where one spouse is working oversees, while the other works within the country, but in an engagement that does not allow them to be continuously at home. They would be available on weekly intervals or fortnight or even once a month. A case was reported of a couple, who are both involved in the disciplined forces, they quickly noted that indeed time for their family was quite a challenge. They said that at times duty calls for their long absence from their children. One way in which they deal with this situation is to create a good rapport with the house help and actually giving them a high pay so as to retain her and ensure she properly looks after their children. They indicated that they do not engage the help of relative because in past instances the relative have either misused their resources while away and abuse their trust and confidence as well. Therefore, in the absence of the parents these families are run by house helps or a relative. In other cases, the children are conveniently tucked into boarding schools, may be if to shorten the period which they would be at home in the absence of their parents.

\subsection{Zombee/Ghost Husbands Phenomenon}

This was a patent trend in Kagio town and the surrounding areas in the County. This phenomenon is rampantly growing especially in the larger central Kenya region. In this case the presence of the husband in a household setting is not realized, not because they are absent, but because they are passive. They are withdraw and do not support in the family well- being whatsoever. Their withdrawal and passiveness is further aggravated by the increasingly continued rather expected contempt form their wives. The wives chose to move on with the assumption that their husbands do not exist and bravely shoulder all the household responsibilities, from breadwinning to domestic chores. The husbands are mainly miserably engulfed in alcoholic addiction and idling habits. 


\subsection{Single Parents Phenomenon}

This is another prevalent trend in the family setting in Kagio town. The classification of the various categories of the single parent family observed by the researcher is greatly informed by the insightful works of P.N.Wachege on Third Millennium African Single Mothers \& Mother Widows. The single parents families identified have been classified into two categories namely; single parents by choice and single parents by default.

\subsection{Single parents by choice}

This is an increasingly growing trend not only within the area of study but in the society at large. There are various reasons that inform this choice of parenthood. Just as Wachege describes, some are those with a commitment phobia. They do not want by all means to be tied down with any men in their life. They want freedom for their freelance kind of lifestyle since for them marriage curtails such and is indeed a bondage. They do not want to be answerable to any man whatsoever for any action.

The reasons behind their commitment are inspired by various situations, sometimes previous betray in relationships, the story of their upbringing, where by some grew up in the face of domestic violence and would not want to experience the same. Some experienced the pain of their parents failed marriages and they have the fear of having to go through the same. For others having grown up in single parents households and having been socialized into that kind of lifestyle they feel they need to emulate their mothers whom they think was a lot happier than a majority of their married counterparts or simply a choice of lifestyle for the pleasure that comes with it. Others are those that Wachege would describe as single parents for the reason of academic pursuit/ erucidition advancement, a large number of single parents who would suitably fall under this category in Kagio town are not necessarily engaged in academic pursuit but in entrepreneurship, but there are those as well who originally belong to kagio but have settled elsewhere and are of this status. An experience of one of the respondents explains this situation better.

Wakini is a 36 years old accountant and mother of one, after graduating from high school at the age of 19 years she joined college to pursue a career in accountancy, while in college she got into a relationship that was serious and pointed to marriage, After three years of dating her boyfriend who had then left college and started working, he proposed marriage, but Wakini declined and asked the young man to wait until she was through with her studies to the level she wanted and at least secure a job as well, The relationship did not last long after, since the man decided to move on and marry another person. with the support of her family member Wakini furthered her studies and this earned her a better job and better remuneration. After all this achievement, a good house in the suburbs of Nairobi and a nice car and quite a good pay she now felt it was time to settle down in marriage and build a family, she was now open to dating, she had just clocked the age of thirty and still a committed Christian. As she says, this was the beginning of so many unfortunate and heart breaking engagements in her life. Some men she dated would openly acknowledge intimidation after their knowledge of her status most probably because they earned less money, and did not own as much as she did. Others came along and they turned out exploitative and abusive of her resources. When she was 34year of age and all the nerve wrecking and heartbreaking experiences she decided to look for a good married man whom she fathered a child with and then committed her life to taking care of the child without any commitment to the man. As she acknowledges, ideally she would have loved to be in a marriage relationship, but with her experience she feels she is much better off and happier as a single paent."

The other category of single parents identified by the researcher was that of single parents by default. They mainly include: Widowed single mothers, divorced and separated single parents. There is an increasing trend of widowed single mothers at a very young age, especially in the area of study. Early deaths of their husbands were attributed to such as committing of suicide, extrajudicial killings, death as a result of alcoholism/illicit brews among other natural causes. The rate at which cases of divorce and separations are being experienced is alarming. The circumstances behind this break ups are upsetting. The situation is startling among the 'elite' of the society or rather those considered as liberated in the society.

Here is a serious and high ranking academician in her own rights and a mother of three. She gladly enjoyed a happy marriage for 13. (Details not explicitly disclosed for the sake of the respondents privacy). She had soon gotten married after her undergraduate studies and then with the support of her then very loving and well to do husband, she enrolled and completed her Master's degree. She got a PhD scholarship overseas and with immense support from her spouse and other family members went ahead to pursue her doctorate. After of one year into her studies she received news that would break her heart and made her to shed the most tears of her life. This time the spouse was threatening that she should never come back home because by the time she's done with her study he would be long gone. She 
decides to discontinue here studies and go back home to check out what the problem was. When she arrived home she was gladly met by her spouse who kept on insisting that she should not have come home, because he had gotten another woman for himself, reason being she was growing too big too fast and she was getting out of his hands. Despite his supportive demeanor he was really threatened and in fear deep down inside him. That brought an end to their marriage and she later pursued her doctoral studies. Her experience endeared her to engage in the field of counseling and social science whereas her line of study was initially in pure sciences.

It is important to note that the single parents' household are largely those led by women, more often the men who would otherwise end up as single parent do remarry after their separations, divorce, and death of their spouses or any other circumstances that would render them the status of single parenthood.

\subsection{Children Led Families}

This is a trend where older children take care of their younger siblings even before attaining the age where they could be considered adults. Some of the circumstances leading to this phenomenon are disquieting and calls for serious attention to the ailing family setting in our African society. There are households where children as young as 10 and 8 years have to do the cooking, the cleaning and laundry for the younger children and others have to even fend for their sibling.. Both the mother and the father wake up early to go and drink alcohol without minding the welfare of their children, only to come back at dusk so drank and more often than not they violently turn against each other, disturbing even the peace of their neighbors. The quarrels range from the involvement with different sexual partners at their brew dens, to blaming of each other on irresponsibility over their children. Other children have their mothers parting for work in the city and leaving them behind with their fathers who apparently are never at home, and are mostly found in the village's brew dens.

For some, they have been orphaned through their parent's suicide-murder after prolonged quarrels, others through H.I.VI AIDS after involvement in extra- marital affairs and are left under the care of an ageing and ailing grandparent, who is no longer able to take care of them. Largely, the eldest children are forced to drop out of school to fend and care for their siblings and the ageing grandparents.

\section{A reflection on the explanatory causes to the trends in the A.C.F}

This reflection is in view of the impact of women liberation. It is in acknowledgement of the fact that, the explanatory causes identified can also find their explanation under different circumstances, nevertheless, the contribution of the impact of women liberation cannot be overlooked.

\subsection{Inferiority- Superiority Complex}

This is one of the outstanding reasons that seemed to explain the various situations or trends confronting and threatening the fabric and existence of the A.C.F. such as separation, divorce, present yet absent husbands among other situations.

After many years of efforts to emancipate and empower women in the society, a lot has been achieved, Fortunately or unfortunately, consciously or unconsciously, avoidably or unavoidably, more than a few of these women develop an attitude of contempt for their male counterpart and in our case contempt towards their husbands. In other cases the attitude of contempt may not have been displayed but the manifestation of notable self assertiveness, independent mentality and radical liberalism, based on whatever kind of liberation approach or initiative that has impacted on the woman, they are easily taken to be disregarding or challenging the place of their spouse in the marriage, as much as the case may not be so. This phenomenon makes some husbands withdraw from active participation in their marital life and if only to conceal or pacify themselves from the resultant frustration of the status quo in their marriages, they turn into non productive alcohol addiction and thus the zombie husbands phenomenon identified in the study. Husbands in this situation may also react by way of turning violent against their wives, derogatively abusing them, sometimes even in the presence of their children or use other in humane means to hit back on their seemingly "high headed wives" leading to separation or even divorce in the families. The male spouses may end up committing suicide as a way of dealing with their perceived frustrations, thus resulting to widowed single mothers. The men in this predicament, may chose seek solace in less assertive partners. More often, the partners tend to be people whom they share the same sentiments in regards to their wives. It largely turns out to be their house helps, who are also considered subjects to their wives "power". The men may seek solace in young school girls who they feel they are in a position to control, more than they would do with their wives. Some of these husbands will secretly guard these engagements, while others will do them in the open in an attempt to hit back on their wives, but only end up tearing the marriage apart. 


\subsection{Culture Shock}

This was a profound contribution from one of my respondents, Prof D. Waruta who argued that "people are stories" That an individual is a making of their experiences and exposures in their life. That if one wants to understand a person better, there is need to listen and understand the story of their life. Perhaps this is what in other words sociologist would describe as the process of socialization which largely determines who a person is, in terms of their worldview, values, or even personality. This was the premise of our discussion as we set out to examine the impact of various modes of women liberation upon the African Christian family with my respondents. He further argued that if any initiative or whatever change has to be largely successful and without much repercussion there is need to understand the contextual background against which the individuals involved have come from. If the perceptions is that worldview inappropriate, then the process of change should begin with addressing the seemingly distorted worldview before introduction of the eventual product of change. To relate this articulation to this study he noted that, the many problems that are being experienced in the marriage or family circles in regards to men and women misunderstanding is a reactionary effect of culture shock. More than a few of the men and women in marriage especially in the African society have been socialized into a patriarchal oriented culture. The understanding of their roles and structure of relationship is largely against this background. The noble efforts of women liberation gradually transform the woman to look at and understand life differently. This package of changes is more readily acceptable to the women since it is perceived as emancipating and in favor of them. Nevertheless, there are largely no considerations or mechanisms put in place to help the male counterpart to reasonably come into terms with the given changes in the gender relational equilibrium or even to help them let go of their underlying perceptions and outlook in regards to gender relations. This perceptions are not a making of their own but that of their upbringing. Therefore the men end up feeling aggressed, intruded and even shocked by the more sudden change of the women in their lives. Some men successfully adapt to the changes but not without help from their spouses and other support initiative. Those who are not able to adapt to the changes, respond by way of retaliation through for example, wife battering, engagement in extra marital affairs or refusal to participate in provision for the needs of the family. Others who do not successfully adapt, attempt to run away from the realities of this changes. They do so by for instance; engaging in alcoholism, committing of suicide, murder of their spouses or seeking solace in partners who can identify and respond to their concerns and fear or even practically ran away from their matrimonial homes.

\subsection{Overshadowing women oriented machineries}

To avoid being mistaken for an anti-womanist or anti-women liberation, I need to say that indeed the works and achievements of the various women liberation initiatives are plausible. However, a deaf ear, blind eye and an insensitive feeling cannot be accorded to the ever more increasing impact of the initiatives in the society, positive or negative.

The presence of women empowerment institutions/organization or programs, both formal and informal is evident nearly in every city, suburbs and rural areas. The subject of women liberation and empowerment has a huge media presence as well. Access to financial support, Legal support, education and even health services is much easier for the women than it is to their male counterpart. A response by one of the respondents was a clear indication of the above assertion.

Kinyua wa Muthii is a "mkokoteni" operator at Kagio market, he shared the story of his life with a lot of sadness. He well remembers way before free primary and secondary education came around, he and his two siblings- a brother and a sister- could not continue with their education due to financial difficulty. A short while after being at home the sister was able to go back to school following a sponsorship programme for the girl child that came to their village. Kinyua and his brother had to engaged in manual jobs in the neighbourhood to keep life going, but the feeling of frustration rather than joy engulfed them as their sister seemed to do well. She soon finished her secondary education and was again sponsored to taking a computer course and there after got a job in Nairobi and left the village. The life in the village was full of frustration and they soon found themselves engage in consumption of illicit brew. His brother engaged in theft, and one day faced the wrath of an angry mob after stealing and was beaten to death. Witnessing what had happened to his brother, he decided to leave home and find another life in Kagio market, where he has been since then. When people show contempt or seem to despises me, I always think back and wonder what life would have been if only I had gotten the chance to go through school like my sister, sometimes he cannot help it but drink alcohol to pacify his frustrtion.

Rarely are there male or men empowerment forums to be sported in the villages, town, and cities, not to suggest that there is need for such, but rather just to point out the absence of it. The onset of such forums, would just lead into a never ending vicious cycle or battle between oppressed and oppressor, whereas what is needed is liberation for all in view of promoting more authentic gender relations. The predominance of the women liberation machineries has been 
largely interpreted as waged war against the male counterpart. If they have not already resigned to defeat, then they are fiercely defensive of their socialized positions in the gender relational balance. Those who have resigned to "defeat" have done so by either looking for ways and means to pacify themselves from the reality or simply accept the new status defining the terms of their relationships. Some who fight back end up turning their homes into battle grounds and the persons who suffer most are children in such kind of families.

\subsection{Demand from Single Mothers by Choice}

Technologies such as test-tube babies and sperm banks are not common place in Africa. A woman will often conceive through a sexual encounter with a man. The phenomenon of single motherhood by choice with the exception of the option of adoption requires that a man be involved. As the study gathered, due to the nature or attitude of non- committal to men in their lives, the aspiring single mothers make a very careful choice of the men with who to father their child or children. Responsible, stable and well to do married men easily qualify for their choice. Since the married men cannot contend with having their marriages breakdown, they are highly likely not to come after the woman, therefore guaranteeing the sought after status of single parenthood. In an unfortunate circumstance where the extra- marital involvement is discovered by their spouses before they take off or after, it may lead to divorce or separation. The man in this case, more often than not is left as a loner. They are not welcomed by their betrayed wives nor their mistresses. Children born under the circumstance of such an affair, grow up and at some point demand to know their patriarchal identity. With the generally high level of assertiveness and technology at their disposal some of these children are able to trace their biological fathers and once they surface in their lives, it leads to marriage disputes and sometimes eventual breakdown.

\subsection{Lack of Conjugal Satisfaction}

This situation is widespread. Clergy men encountered, attributed this as one of the dominant challenge they have been handling while arbitrating or trying to restore otherwise breaking marriages among their congregants. Dr, Wangombe, a pastor and scholar in his own rights, articulated this as a predominant cause of trouble in the marriage relationships. Pastor Obuya and Rev maina Thunguru similarly pointed out that indeed conjugal relation is one of the primary reasons for getting into marriage, due to its procreative role and also due to its centrality in promoting emotional and marital bond, however it is among the leading underlying factors of marital crisis.

\subsection{Rivalry/Strife}

This is a phenomenon that explained the circumstances /challenges facing the African Christian family setting, largely where the spouses involved were both educated, well to do and ascribing to the women liberation ideologies. The rivalry/ strife is evident in every aspect of their life from buying of new dotties, cars, phones, earning more money than their spouses to even the ability to entertain their extended families and friends. A lot of extra hard work is involved just in an effort to ensure resources needed to keep up are available. They end up not having time for one another and not even for their children as they hop from one business meeting to another from meeting one client to the other, traveling for jobs and acquiring more degrees. Eventually the marriage bond weakens and may eventually break, causing lots of emotional and psychological disturbance to the children. This also aggravates the phenomenon of absentee parent with its resultant effect.

\subsection{Family planning}

The research found that as much as men were aware of the empowerment of women through the reproductive health programme, more than a few were very passive if not ignorant about what happens with their spouses. They largely considered it a woman's business, casually dismissing it as the responsibility of the women to ensure they don't get unplanned pregnancies. The lack and presence of family planning, has brought, several problems to the African Christians families. If the woman does not take precaution or they do, but it happens not to be effective and eventually find themselves pregnant against their plan/ wish as couple, some of the husbands turn to making life impossible for such women constantly abusing sometime running away from home.

Some women take the other extreme and refuse to give birth, despite the will of their husband. The husband are no way in control of their reproductive health, given that it was considered a "women's business". They are therefore 
rendered helpless in such situations. To fight back the frustration, they may choose to have an affair, which may eventually break up the marriages.

\subsection{Lack of premarital / marital counseling}

This was a situation largely identified by the church leaders. A lot of the so called African Christian families in the society, have not been ideally formed through the Christian doctrine and teaching, where the pre -marital counseling is a requirement before any couple is joined together in Holy matrimony. Just because they describe to the Christian faith, they may not have followed that route, but rather opt for come we stay kind of marriage for reasons which this study does not look into at the moment. Even though having well followed the said requirement after come up -stay, they find them way to church and continue to identify themselves as Christians families.

With a handicap of information and knowledge impacted on African Christian families and various aspect of successfully relating a marriage and eventual parenting and situation, they several problems are likely to arise and challenge this kind of families, and living them with no place or knowledge to fall back to in order to rise above the various challenges the encounter. All the same, some are ignorant of the values/knowledge impacted on them during the premarital counseling or any other marital counseling forums.

It is important to note that the task of pre- marital counseling has largely been left to the confines of the church as pastor's duty. What of those that engage in civic marriages traditional marriages as it is done in civic marriages traditional marriages as it is done in the contemporary society? Where is their share of advice, because they are African and sometimes Christians too, and their marriages or families are not exempted from the threats.

\subsection{Lack of communication /skepticism}

Women liberation initiatives have largely remained a woman's domain. A lot of the programmes do not bring the men on board in the process of liberation of the women, which as Wachege notes in his justification on the involvement of men in women liberation is of vital importance if any meaningful liberation is to be realized. He argues that, women liberation is not a confine of women, because by the very essence of the nature of human being, women and men are complementary beings, distinct and not dichotomized.

Women largely claimed that they had not and could not inform their husband of several of their empowerments engagements claiming that they are skeptical of whatever dealings their wives are engaged in, especially if it is about empowerment. Some women enlist in 'chamas' or some financial supporting programmes, they take loans and do not inform their husbands, only for them to turn to their husbands, when they are unable to repay back and are threatened with auctioning of their families properties, here not the extended family, but those with their husbands. Some husbands are met with a surprise of empty houses upon return from work, only to learn that their household items were auctioned by a group of women and financiers from who their wives had borrowed a loan.

\section{Implications of the Situation of The African Christian Family}

Family is very core to human existence. As seen earlier in the study, it is a primary institution, for ensuring the continuity of the human race structurally and functionally. It is also primary institution of socialization and formation of individual identities. Threatening the existence of the family implies putting into jeopardy the fabric of human existence and thus the society.

\subsection{Spiritual implications}

\subsubsection{African religiosity}

A religion has seven significant elements, which include the ritual dimension, the doctrinal dimension, the social aspect, the moral/ethical aspect, the experiential aspect, the material culture and the mythological aspect. It is through the family, that the dimensions of religion in the African context are actualized. There is no compartmentalization of life in the African worldview, that is to say, no demarcation between what is known as spiritual and secular. Every aspect of life in the African worldview has an underlying spiritual/divine connotation. Through the socialization process, like transmission of values and the communities' way of life to be young ones using oral narratives, lots of doctrinal teaching are passed on as well. Relationship with the divine are explained. Initiation rites are largely marked by rituals giving the initiation process 
divine as well as social significance. The communal approach to life provided for the community of faithfuls in the African traditional society. Moral and ethical values are instilled, through passing on of information to the young ones as they grow up knowing the do's and don'ts, though the constant process of socialization. Therefore, if the existence or being of the family in the African society is threatened, then the very religiosity of the African people is at stake as well.

\subsubsection{Church as family}

Church is the largest extended family in the world. There is even a more lasting community that the earthly extended family. One who believes in Christ, becomes part of a much more enduring family than his earthly family. When physical life is over a believer is expected to live with God's family in the New Jerusalem. The earthy family is the community where one is expected to get their values and beliefs and early training in life, on the other hand church is considered the community where one gets their values and beliefs and early training in Christian life. It is from the family that one established the deepest and most enduring relationships of life. It is also where one drives their name and identity as a person as well as find a sense of purpose in life, for making the family what it is. Similarly the church is the community where Christians establish the deepest and most enduring relationships in life in Christ, it is where one derives their name and a sense of purpose, in the Christian community/church, through serving God and serving others.

The African family commonly has its leader as a wise old-man usually the eldest father in the family. The family is also where one is corrected and disciplined if they misbehave. It is in the family that people learn things by sitting around the fire place. Decisions are made by discussing things together, sharing ideas and then coming to one opinion, which is present to the leader for the family for approval and blessings. In the family, celebration such as child birth, naming ceremonies and weddings are held. Members of the family ideally share meals together.

Comparatively, the church has a leader who is Christ himself (1 Corinthians 1:30), it is in the church that faithfuls are corrected and disciplined if they misbehave. Church is the family/community where believers learn the principles of godly living by telling the stories about the great heroes of faith found in the bible. It is in the church, that celebrations and rites such as, baptism, weddings among others are observed. In church bread is eaten together during the sacrament just like in the earthly family people are born into the church family through salvation, thus ensuring continuity of the church family.

The above illustrations are a clear pointer that indeed, the ideal of the church and the truths of the gospel as seen earlier in the study on Christian teaching on and about family through the bible cannot be expressed without the idea of the family in existence. If the essence of the family is destroyed, then it can prove very difficult to express spirituality in both the African and the Christian fraternity.

\subsection{Social implication}

Family is a primary institution of socialization, formation of personal identity and transmission of values. The threatening of the existence and being of the family posses a great threat to the very fabric that holds the society together. The loss of family or distortion of its ideals goes a long way to affecting for instance relationships, well being of individual and the community at large as well as the stability of the society.

Primary role models are found in the family, either through the father or mother figure or both, lack of it goes a long way in no exposition on how to play the same role later in life for the children, in such families. If a people are not informed of their origin and the story that makes up their life to what it is at a given time, then it becomes even difficult to emerge with a clear identity of one self thus the prevalence of identity crisis, as individual a community and a culture. If the culture of a people and its values is not constantly transmitted, then this crates a cultural void which is likely to be filled in by any other ideological cultural values that come along the way, again posing a threat of the extinction of the original culture and its values.

Critically examining the above articulation, it only deems that the significance of the well being and existence of the ideal family cannot be over-emphasized, failure, distortion or lack of it by whatever means posses very serious threat to the social fabric of the society. With family instability, there comes along various challenges that threatens even the mere continuity of the human race. For instance, as it emerges in the study, issues such as infidelity, suicide of spouses, suicide of children, murder of spouses, alcoholism, homosexuality and lesbianism, rape, divorce and separation, an issue that a society will have to content with, in the face of an ailing marriage and family institution 


\subsection{Psychological implications}

As a child grows up, there are several development stages that they encounter through to adulthood. According to Erick Erickson a psychological, human development is marked by psychological, human development is marked by psychosocial stages, which span from birth to death and focuses on tasks at each state that must be accomplished to successfully navigate life's challenges, Erick Erickson outlines eight stages through which a healthy developing human should pass from infancy to late adulthood. Fore most is the infancy stage ranging between (0-12months), hence the task to be accomplished is finally for the individual to be able to treat or mistreat, the presence and reassurance of a mother is important, because the child exploration is is on such as can I trust this new world or not. If the child is for instance fed well, given warmth they develop a concept of trust, if they are abandoned and mistreated, or abandoned, they develop a concept mistrust.

Secondly is the stage ranging between (18-3 years) here the task is to develop autonomy or shame and doubt. The presence of the parents is significant in this task. The exploration question in the child is "is it okay to be me?" tasks such as toilet training, clothing themselves among other tasks will help develop the autonomy in a child if there is failure, the child develops shame, doubt because of lack of assurance and successful navigation.

Third is the stage between 3-5 years. The task leads to the development of initiative or guilt. The child explores the fact that, "is it okay for me to do, move and act?" if there is constant reprimand and caging of the child, they are likely to develop initiative, but a feeling of guilty or inappropriateness in the attempt to do anything by and for themselves.

At age 5-13, competence is to be developed, the child becomes industrious and if the stage is not successfully navigated, there is development of an inferiority attitude. Here the neighbours, school, or general the communal interaction is important. At age 13-21 years identity is established failure to which there is emergent role confusion. At age 21-30 years, the individual successful engages with friends and partners and established romantic relationships, if there is failure an attitude of isolation is developed. At age 41-65 years the individual are supposed to be generative, through successful working, parenthood, among other activities, failure of which leads to stagnation in life. The individuals seek to make their life count at 65 and above the individual engage in a reflective experience of whether it was okay to have been themselves which makes then establish an ego integrity or despair with life and wish to exit as soon as possible.

Another psychologist, by the name Sigmud Freud a psychosexual theorists argues that neurotic adult behaviour are a manifestation of childhood sexual fantasy and desire. To illustrate the necessity of an ideal family setting for successful growth and development we will look at the third stage of development outlined by Sigmund Freud. It is known as the Oedipus complex, manifest in both boys and girls. This is the phenomenon when the body desire to sexually possess. This is the phenomenon where the boys desire to sexual proper resolution, lies within the child's reversion of the feeling to identifying with parent of the same sex. Son-father competition makes the son identity with the male and daughter-mother competition resolved makes the daughter identity with the female. Unsuccessful resolution might lead to neurosis paedophilia and homosexuality.

Critically if the family institution is unstable or broken or distorted, there are various psychological implications bound to be realized. For instance in reference to Erick Erickson theory, if a mother is absent from the child life perhaps as early as three months and it so happens that the care giver mishandles the child by for instance, not comforting, no proper feeding among other possibilities, the child is likely to develop an attitude of mistrust or scepticism. Secondly if the parent is again absent during this age of crucial training to develop autonomy and for instance the caregiver is not up to the task, then there is a likelihood of bringing up an individual who is shameful and does not believe in themselves. Of even greater concern is the stage between 3-5 years as outlined by Erich Erickson, a stage where the child is highly explorative. Most care givers are not just assigned the role of looking after the child, rather they are more cases than not expected to attend to all other households duties or chores, in the effort to minimize the destruction from the child and children under their care, the tend to use whatever means to cage the child/children in order to ensure minimal disturbances or interruptions as they attend to other domestic chores. This may end up affecting the child's development of initiative in life.

It is therefore important to safeguard the well-being of the ideal family, in order to promote proper development and wellbeing of individuals and therefore the society.

\subsection{Economic implications}

Following the finding on the situation of the A.C.F in view of impact of transformational waves, of women liberation movements(s), the family stability is at stake. Family stability and productivity in the society are heavily intertwined. For 
example a husband turned zombie and alcoholic addict, is likely to be economically unproductive. When individuals have access to finances which they are not readily equipped to handle, it is likely to lead to an economic downfall of the individual. Those who are successful in putting to good use the fund; usually experience a huge financial breakthrough which in turn has a large trickledown effect, to the larger economy of the society and life style. For example, there better access to education, better access to food and clothing, among other basic amenities.

\section{References}

Arnold F.X., Woman and Man: Their Nature and Mission, New York: Herder and Herder, 1963.

Boff L. and Boff C., Introducing Liberation Theology, Maryknoll, New York: Orbis Books, 1987

Clark, E. and Richardson H., Women and Religion: A feminist source book of Christian thought, New York: Harper and Row, 1977.

Clifford, Anne M., Introducing Feminist Theology, Maryknoll, New York: Orbis books, 2001

Cone J.H., A Black Theology of Liberation, 2nd ed., Maryknoll, New York: Orbis books, 1986

Cott, Nancy F., The Grounding of Modern Feminism, New Haven: Yale University Press, 1987

Dickson K.A., Theology In Africa, Maryknoll, New York: Darton, Longman and Todd, 1984

Edet R. and Ekays B., "Church Women of Africa: A Theological Community" in F. Virginia and M.A. Oduyoye (eds.) With Passion and Compassion, Maryknoll, New York: 1989.

Fabella, V.M. Oduyoye M. (eds.) With Passion And Compassion: Third World Women Doing Theology, Maryknoll, New York: Orbis Books, 1988.

Frostin P. Liberation Theology in Tanzania and South Africa; A First World Interpretation, Lund; Lund University Press, 1988

Faludi Susan, Backlash: The Undeclared War Against American Women, Three Rivers Press, 2006

Fiorenza, E.S., Wisdom Ways: Introducing Feminist Biblical Interpretation, Maryknoll, New York, Orbis Books, 2001

Freire P., Pedagogy of the Oppressed, London: Sheed and Ward, 1972

Gutierrez, G., A Theology of Liberation, History, Politics and Salvation, Maryknoll, New York: Orbis Books, 1973

Getty-Sullivan, M.A, Women In The New Testament,2001

Hinga, T. M. "Women Liberation in and Through the Bible: The Debate and the Quest for a New Feminist Hermeneutics", in ACS CHIEA, Nairobi, Vol. 8, No 4, 1990

Hoff S., Christina, Who Stole Feminism? How Women have betrayed Women, Touchstone /Simon \& Schuster, 1995

Kinoti H., African Ethics: Gikuyu Traditional Morality, Amsterdam, New York, NY, 2010

Martin F., The Feminist Question: Feminist Theology in the light of Christian tradition, Edinburgh: T\&T Clark, 1994

Mahan, B and Richesin L.D. (eds.), The Challenge of Liberation Theology: a first world response, Maryknoll, New York: Orbis books, 1981

Martey E. African Theology: enculturation and Liberation, Maryknoll, New York: Orbis books, 1996

Mhagama C. "The Church as a family of God: A Biblical Foundation", in P.Ryan (Ed), The Model of "Church-as-Family" Meeting the African Challenge, CUEA publications, 1999

Mugambi J.N.K., From Liberation To Reconstruction: African Christian Theology After The Cold War, Nairobi: E.A.L publishers, 1995

Mugambi J.N.K., African Christian Theology, Nairobi: Heinemman Kenya, 1989

McRobbie, A., "Post Feminism And Popular Culture", Feminist Media Studies, Vol. 4, No 3, 2004

Nasimiyu, A. "Christology and an African Women's Experience", in J.N.K Mugambi and L Magesa _Jesus In African Christianity, Experimentation And Diversity In African Christological Initiatives, 1989

Nasimiyu R. "Women in Colonial Economy of Bungoma, Role Of Women In Agriculture", 1920- 1930. In Gideon s. Were (ed.) Women And Development In Africa, Nairobi: Gideon S. Were, 1985

Ominde S. The Luo Girl from Infancy to Marriage, Nairobi: Literature Bureau, 1986

Polllit, K., "Reasonable Creatures: Essay on Women and Feminism", Vintage, 1995

Strossen, N., Defending Pornography: Free Speech, Sex And The Fight For Women's Rights, prentice hall \& IBD, 1995

Tshibangu T.," The Task of African Theologian", in K.A. Kibi \& S Torres (eds)African Theology en route, Maryknoll, New York: Orbis books, 1979

Wachege, P.N., Third Millennium Single Mothers \& Mother Widow,2003

Wachege, P.N., African Women Liberation; A Man's Perspective, 1992

Wa Wamwere K., A Woman Reborn, Nairobi; Heinemann, 1980

Zani, P.A., The Family in its African Socio-Cultural Context, in P.Ryan (Ed.) The Model of "Church-as-Family": Meeting the African Challenge, CUEA publications,1999

Kenyatta, Jomo, Facing Mount Kenya, New York Random house,1962

O'Donavo Wilbur, Introduction to Biblical Christianity from an African perspective, Masthof press, 2009

Bickerman, Elias J. The Name of Christians, The Harvard theological review , 1949

Bickerman, Elias J. Studies in Jewish and Christian History ,Brill publishers. 